\title{
Between Soft Legality and Strong Legitimacy: A Political Economy Approach to the Struggle for Basic Entitlements to Safe Water and Sanitation
}

\author{
Bas de Gaay Fortman* \& Michela Marcatelli**
}

\begin{abstract}
This article argues that the internationally declared "human right to safe water and sanitation," although characterized by soft legality, may yet support universal access to such basic entitlements by virtue of its strong legitimacy. From a strategic perspective, human rights do indeed provide legitimacy to collective struggles aimed at realizing socioeconomic justice in contexts in which the human dignity of the poor is being structurally denied, often including even a simple enactment of their basic rights. Beyond the current focus on legality and in connection with the global development agenda beyond 2015, the authors draw on a number of water-related legal and political cases meant to illustrate distinct human rights strategies. They explore the impact of contextualized "upstream initiatives" and the use of abstract rights as instruments towards securing concrete entitlements, to be seen as a crucial complement to the "downstream" ventures still favored by those primarily concerned with the protection of human dignity from the perspective of international standard-setting and supervision.
\end{abstract}

* Bas de Gaay Fortman is the Honorary Chair in Political Economy of Human Rights at Utrecht University.

** Michela Marcatelli has worked as an intern at the Netherlands Institute of Human Rights. She is now Ph.D. researcher at the International Institute of Social Studies (ISS) of Erasmus University Rotterdam.

The authors wish to express their sincere gratitude to Kelsi N. Steele M.A., intern from the University of Cincinnati (Juris Doctor program), for her excellent assistance in tracing sources and editing texts. 


\section{INTRODUCTION: UP/DOWNSTREAM EFFORTS ON THE RIGHT TO WATER}

Now that the deadline for achieving the United Nations Millennium Development Goals (MDGs) has passed, it is high time to assess the progress made and the need for further improvement on Target 7C-the goal of increasing access to water and sanitation, given that without access to these items life is not sustainable. In its "Right to Water" declaration the UN General Assembly acknowledged this,

Deeply concerned that approximately 884 million people lack access to safe drinking water and that more than 2.6 billion do not have access to basic sanitation, and alarmed that approximately 1.5 million children under 5 years of age die and 443 million school days are lost each year as a result of water- and sanitation-related diseases, ... [the United Nations General Assembly declared] the right to safe and clean drinking water and sanitation as a human right that is essential for the full enjoyment of life and all human rights. ${ }^{1}$

This way of responding to a serious deficit in the international protection of human dignity by declaring a new right is indicative of a prevalent confusion in international "human rights-based" approaches ${ }^{2}$ to tackle deficient sustainability of daily livelihoods. Clearly, it is actual access to safe water and sanitation that must be regarded as an essential condition to sustain human life rather than just its declaration as an abstract "human right."

Yet, the resolution was accepted with 122 votes in favor, none against and forty-one abstentions, the latter apparently all based on concern with its utterly soft legal character. ${ }^{3}$ Indeed, the UN makes no mention of any legal or political consequences of its vague declaration of water as a human right, neither in respect of international law nor in terms of national obligations of the member states. Instead it:

1. The Human Rights to Water and Sanitation, 64th Sess., Agenda Item 48, at 3-4, U.N. Doc A/64/L.63/Rev1 (2010), [hereinafter Human Right to Water and Sanitation].

2. The term "human-rights based approach to development" was coined by the United Nations Development Programme (UNDP). See UNDP, Integrating Human Rights with Sustainable Development 9 173-74 (1998). The human-rights based approach to development "describes situations not simply in terms of human needs, or of development requirements, but in terms of society's obligations to respond to the inalienable rights of individuals, empowers people to demand justice as a right, not as a charity, and gives communities a moral basis from which to claim international assistance when needed." With regard to water, see here particularly Emilie Filmer-Wilson, The Human Rights-Based Approach to Development: The Right to Water, 23 Netherlands Q. Hum. RTs. 213 (2005). As to access to water as a human right see Stephen Tully, A Human Right to Access Water, 23 Netherlands Q. Hum. Rts. 35 (2005).

3. Press Release, General Assembly, General Assembly Adopts Resolution Recognizing Access to Clean Water, Sanitation as Human Right, by Recorded Vote of 122 in Favor, None against, 41 Abstentions, U.N. Press Release GA/10967 (28 July 2010), available at http://www.un.org/press/en/2010/ga10967.doc.htm. 
Calls upon States and international organisations to provide financial resources, capacity-building and technology transfer [. . . ] in order to scale up efforts to provide safe, clean, accessible and affordable drinking water and sanitation for all; and

Welcomes the decision by the Human Rights Council to request that the independent expert on the issue of human rights obligations related to access to safe drinking water and sanitation present an annual report to the General Assembly $[\ldots]$ and encourages her to continue working on all aspects of her mandate. ${ }^{4}$

In sharp contrast to this creation of a weak "downstream" declaration, is the strong "upstream" initiative of Sulabh International, an Indian-based social services movement founded in $1970 .{ }^{5}$ Working all over India with over 50,000 volunteers it has supported the construction of 1.2 million household toilets and 7,500 community toilet blocks, thus liberating 120,000 Dalit scavengers from their degrading work. ${ }^{6}$ Sulabh has also been invited to help out in neighboring countries such as Nepal, Bhutan, Afghanistan, and Bangladesh, too. ${ }^{7}$ Furthermore, it has taken up programs in collaboration with both United Nations entities and nongovernmental organizations (NGOs). ${ }^{8}$

The Sulabh Movement combines innovative "hardware" (technology) with inspiring "software" (education, including "conscientization" in respect of human dignity and human rights). It aims not just at sanitation for everyone but also at "restoring human rights and dignity to scavengers, ensuring their social integration, and poverty-alleviation, on the one hand, and the prevention of environmental pollution and promotion of sanitation, health and hygiene, on the other." ${ }^{\prime 9}$ Thus, it has grounded its mission in a strong sense of legitimacy, which will be addressed in the next section.

In what follows, this conceptual response to safe water and sanitation as a human rights deficit is elaborated, starting with current global views and initiatives (Sections 2-4). Human rights-based strategies will be illustrated by a number of enlightening cases of both a judicial and a political nature (5). Next "downstream" efforts in the setting of the United Nations will be further analyzed (6). This leads to a contextualizing approach, again illustrated by informative cases (7). Finally, some conclusions will be drawn on the need for further integration of downstream and upstream efforts towards the realization of people's basic entitlements in situations of abject poverty (8).

4. Human Right to Water and Sanitation, supra note 1, at 3.

5. Meet Sulabh, SulabH InTERnATIONAL, http://sulabhinternational.org/meet-sulabh/, (last visited July 30, 2015).

6. Bindeshwar Pathak, Sulabh Sanitation and Social Reform Movement, 6 Academic J. 14, 23 (2011).

7. Sulabh International Social Service Organization, available at http://www.sulabhinternational.org.

8. Id.

9. See Sulabh Sanitation Movement, available at https://www.youtube.com/ watch? $v=09$ HnaUONNG0. 


\section{LEGALITY AND LEGITIMACY REVIEWED}

Where access to water and sanitation is lacking, both international and national efforts acknowledge that the rights at stake are not just ordinary subjective claims in the sense of expressed personal interests assumed to be protected by law, but essential to life. Generally, contentions based on subjective rights clash with those submitted by others. But human rights protect freedoms and needs so basic that their denial puts human dignity itself at risk. Thus, what may seem to be a simple conflict of distinct interests protected by diverse power positions is placed in a normative context, confronting both interests and the use of power with values attached to human dignity. Because neither the ICCPR nor the ICESCR explicitly refer to water, the issue remains in limbo somewhere between "hard" and "soft" law. In cases where positive law does not yet acknowledge fundamental freedoms and basic human entitlements, ${ }^{10}$ human rights are most crucial for their strength as principles of legitimacy. It is this distinction between legality and legitimacy that merits attention in respect of human rights realization.

Legality as an overriding principle of law (regula iuris) implies no more or less than that both public authority to enforce and private obligation to comply are grounded in formal law that is clear, accessible, and nonretrospective. The separation of the three powers of government is based on a simple division of tasks in this respect: the legislature creates the laws; the executive derives policies on that legal basis and makes decisions to carry these out; and the judiciary determines the meaning of law in cases arising out of conflicting interests. While theoretically this appears simple, practically that is not always the case-such as in cases of judicial law-making. The point is that no matter the significance of legality as a prevailing principle of law, interpretation remains inevitable. But even the highest judicial decisions establishing legality in its concrete implications will need a measure of acceptability to the polity, viz. legitimacy.

Legitimacy is, indeed, a major requisite with regard to the formation and execution of (political) power. Both policies and executive decisions are legitimate only when these are acceptable to those over whom power is being exercised. Although, the right outcome in the sense of political acceptability to those who are being governed remains a crucial standard, there is also a substantive component to legitimacy. Conformity with the right principles - "general principles of law recognized by civilized nations" to use the terminology of the Statute of the International Court of Justice-and the right procedures in the sense of due process. ${ }^{11}$ These two objective founda-

10. Notably, in order to establish genuine legality such acknowledgement should imply much more than just the declaration of an abstract right. The various cases discussed below are also meant to enlighten this point.

11. Statute of the International Court of Justice, art. 38(c), annexed to U.N. Charter, signed 26 June 1945, 59 Stat. 1055, T.S. No. 993 (entered into force 24 Oct. 1945). 
tions of legitimacy are expressed in national constitutional requirements as well as standards formulated in international law.

Democracy is meant to enhance the legitimacy of government through general procedures for decision-making, implying that the majority decides, the minority acquiesces, and the majority respects minorities. Thus, decisions in a democracy need to be governed by support. The general principle involved is that of representative government ("government of the people") as safeguarded in processes guaranteeing the substitutability of public-political power. Yet that is not enough. Participatory government "government by the people") functions as a second pillar of administrative legitimacy. ${ }^{12}$ It is the third principle of legitimate government-accountability ("government for the people") - that is of particular relevance with respect to the judiciary. No matter how clearly grounded in positive law, the public acceptability of judicial decisions requires some solid attention to principles, institutions, and procedures that find their basis in generally acknowledged norms and values. Indeed, even the judiciary's decisions need to be perceived as legitimate in the eyes of their constituents.

It is in this context that international human rights play an increasingly significant role, as these constitute much more than specific legal provisions. Actually, in terms of sheer legality, their impact is rather trivial, as illustrated by the frequent use of the term "soft law." Yet, while that law is not internationally enforceable, the norms that these rights embody may still support conclusive rights in the national legal context. Indeed, the international dimension adds non-enforceable supra-national supervision together with some external pressure towards further incorporation into the law of the land. Conversely, however, where these rights serve as mere declared rights without any legal consequences, their nature of law without remedies may negatively affect a country's legal culture. Hence, a shift in emphasis from quasi-legal international procedures in semi-judicial bodies, lacking any power to enforce their "resolutions," "general comments," and "concluding observations," to human rights as general principles guiding both political processes of emancipation and judicial decision-making, is needed. In the context of safe water and sanitation as internationally recognized basic entitlements, ${ }^{13}$ this article, then, sets out to examine the impact of human rights as modern "regulae iuris" boosting both judicial and political activism. ${ }^{14}$

12. Bas de Gaay Fortman, Human Rights as Regulae luris: An Inquiry into the Dialectics of Legality and Legitimacy, 2 Eur. Rev. Private L. 409, 409-10 (2012).

13. Defined in Section 3.

14. As to judicial activism, see Bas de Gaay Fortman, Adventurous Judgments. A Comparative Exploration Into Human Rights as a Moral-Political Force in Judicial Law-Development, 2 UtreCht L Rev. 22, 22-23 (2006). 


\section{AN OVERVIEW OF DATA ON ACCESS TO WATER AND SANITATION}

Conventional research on water resources focuses on limits to its availability and possible conflicts among competing demands which could derive from conditions of scarcity. ${ }^{15}$ Naturally, such argument has been countered by alternative views, stressing how scarcity, rather than being something "natural," is a "socially constructed and highly politicized concept." ${ }^{16}$ Scarcity of resources above all affects the poor, who are most dependent on water for their daily livelihoods and concurrently have less access to water and sanitation facilities, resulting in entitlement positions most vulnerable to both climate and social change. ${ }^{17}$ The Human Development Report (HDR) on the global water crisis revealed that almost two out of three persons lacking access to safe drinking water survive on less than US \$2 a day and one in three on less than $\$ 1$ a day. ${ }^{18}$

International standards defined by the World Health Organization (WHO) and the UN Children's Fund (UNICEF) state that a minimum of twenty liter per person per day within one kilometer from the household is needed. However, that standard is meant for drinking and personal hygiene only and does not include other basic domestic uses such as cooking or washing for which the personal threshold should rise to fifty liters per day. ${ }^{19}$

Today, 663 million people lack access to basic water and 2.4 billion people to basic sanitation. ${ }^{20}$ This means that these people are forced to collect water from the nearest source available, which may be infected with pathogens and bacteria causing illness and even death. The only alternative would be to spend a great portion of their income on water sold by private vendors. As for sanitation, people have to relieve themselves in plastic bags, ditches, open fields, or on road sides in the vicinity of their households. ${ }^{21}$ All of this negatively affects human dignity and hinders a number of social

15. Clive Agnew \& Philip Woodhouse, Water Resources and Development (2011).

16. Water, Environmental Security and Sustainable Rural Development: Conflict and cooperation in Central Eurasia 9 (Murat Arsel \& Max Spoor eds., 2010).

17. Un Educational, Scientific and Cultural Organization (Unesco), Water in a Changing World, World Water Development Report No. 3 (2009), available at http://www.unesco.org/new/en/natural-sciences/environment /water/wwap/wwdr/wwdr3-2009/downloads-wwdr3/.

18. UndP, Human Development Report 2006, Beyond Scarcity: Power, Poverty and the Global WATER CRISIS 84 (2006), available at http://hdr.undp.org/sites/default/files/reports/267/ hdr06-complete.pdf.

19. Id. at 34

20. UN, the Millennium Development Goals Report 2015, at 58 (2015), available at http://www. un.org/millenniumgoals/2015_MDG_Report/pdf/MDG\%202015\%20rev\%20(July\%201). pdf [hereinafterthe Millennium Development Goals Report 2015].

21. Roberto Lenton, Albert M. Wright \& Kristen Lewis, UN Millennium Project, Health, Dignity, and Development: What Will it Take 25-26 (2005), available at http://www.unmillenniumproject.org/documents/WaterComplete-lowres.pdf. 
benefits deriving from access to water resources. Astutely, Moriarty and Butterworth list the following relationships between water development and human livelihoods: health conditions; labor availability; cheaper water; improved well-being; education; empowerment; community capacity; income; food security and nutrition; and investment. ${ }^{22}$

Seen from the perspective of the Millennium Development Goals (MDGs), ${ }^{23}$ however, the goal of halving the proportion of people without sustainable access to safe drinking water has been achieved well before the deadline set for 2015-with the exception of Sub-Saharan Africa, where access increased by only twenty percentage points. ${ }^{24}$ On the other hand, the UN has now publicly acknowledged that the goal of halving the proportion of the global population with access to an unimproved sanitation facility has not been met. Sub-Saharan Africa, Oceania, and Southern Asia lagged behind the target, although Southern Asia recorded the largest increase in the proportion of people using improved sanitation. ${ }^{25}$

\section{ACCESS TO WATER IN LIGHT OF RIGHTS, ENTITLEMENTS, AND CLAIMS}

Following the disappointing close to the MDG period, there is a growing awareness that in international endeavors to realize basic entitlements such as access to safe water and sanitation, human rights-based strategies cannot be missed. In this respect, people's struggles are tuned to daily acquirement in the sense of sustainable livelihoods rather than abstract rights. Rights

22. Agnew \& WoOdHOUSE, supra note 15 , at 5 .

23. These are internationally declared targets to be reached in 2015. As to their significance and implications see below.

24. The Millennium Development Goals Report 2015, supra note 20, at 58. See also World Health Organization (WHO) \& UNICEF, Progress on Drinking-Water and Sanitation, 2014 Update, at iv, vi (2014), available at http://www.wssinfo.org/fileadmin/user_upload/resources/ JMP_report_2014_webEng.pdf [hereinafter Progress on Drinking-Water and Sanitation], which includes a critique of the MDGs as a strategy to improve the lives of the poor and the lack of effective monitoring. The category of improved sources includes: piped water into dwelling, plot or yard; public taps or standpipes; tube wells or boreholes; protected dug wells; protected springs; rainwater collection. UNICEF, PROGRESS FOR CHILdren: A Report Card on Water and Sanitation (2006), available at http://www.unicef.org/ progressforchildren/2006n5/index_35533.htm. For a critical analysis of such indicators, based on the cases of Kenya and Ethiopia, see Jonathan Chenoweth, Rosalind Malcolm, Steve Pedley \& Thoko Kaime, Household Water Security and the Human Right to Water and Sanitation, in Water Security; Principles, Perspectives and Practices, 317-31 (Bruce Lankford, Karen Bakker, Mark Zeitoun \& Declan Conway eds., 2013).

25. The Millennium Development Goals Report, supra note 20, at 58-59. The category of improved sanitation facilities includes: flush/pour flush to piped sewer systems, septic tank, pit latrines; ventilated improved (VIP) latrines; pit latrines with slab; composting toilets. Public and shared facilities are not considered to be improved. Progress ON DrinkINGWater and Sanitation, supra note 24 , at 40. 
constitute neither more nor less than a commitment towards legal protection of related interests on the part of those holding them. ${ }^{26}$ Thus, in case of dispute, the owner of an object will invoke her property rights. Like other subjective rights, ownership implies abstract acknowledgement of claims based on the right-holder's interests.

Entitlements, in contrast, refer to concrete protected opportunities to satisfy one's needs. Indeed, what makes entitlements meaningful is actual legitimate access to specific resources and actual legitimate command over definite goods and services. Entitlement is concrete, in other words, while the qualification "legitimate" refers to authoritative protection. Naturally, concrete titles may well find such authoritative protection in rights, as is clearly the case when owners who actually possess a property use it to acquire what they need. Hence, "rights-based" action against deficient access to safe water and sanitation will have to focus on entitlements in the first place.

Entitlement then implies possession of an effective title, legal, or extralegal. The difference between rights and entitlements may indeed be summarized as follows:

A right implies neither more nor less than an abstract acknowledgement of claims. Entitlement comes in between rights and claims: it signifies structural protection of making legitimate claims. Legitimacy is distinct from legality as it is a function of both power-actual command-and law in the sense of formal protection. Entitlement implies possession of an effective title, legal or extra-legal. In a political economy perspective it signifies legitimate access to resources and/ or command over a good or service in a specified use. ${ }^{27}$

Thus, from a political economy perspective, an entitlement signifies structural protection of acquiring what people need. A claim is an actual act of acquirement. For example: the owner of a water pump is generally presumed to be free to use her property on the basis of that right, which includes the presumption of an entitlement to pump water. But it is possible that another person is also entitled to do so, based on a more specific right: for instance a tenant on the property of where the pump has been placed. If both claim access to that water at the same time, the court dealing with the dispute will have to weigh the relative strengths of the respective rights as well as the different interests of the parties, thus assessing their entitlements.

Now, a general problem with human rights in situations of actual deficits, such as described above, is that these have the character of declared rather than attained rights. They are, in other words, rights without entitlements. They are supposed to protect-access to safe water and sanitation-but still must be attained. Consequently, "downstream" (top-down) efforts through

26. Rudolph Von Jhering, Law as a Means to an End 49-50 (1913).

27. Bas De Gaay Fortman, Political Economy of Human Rights: Rights, Realities and Realization 24 (2011). 
international target-setting and adoption of human rights standards coupled with provisions for monitoring and supervision need to be matched by "upstream" (bottom up/grassroots) human rights-based struggles. This is illustrated in the following figure:

\section{Human rights in an upstream perspective}

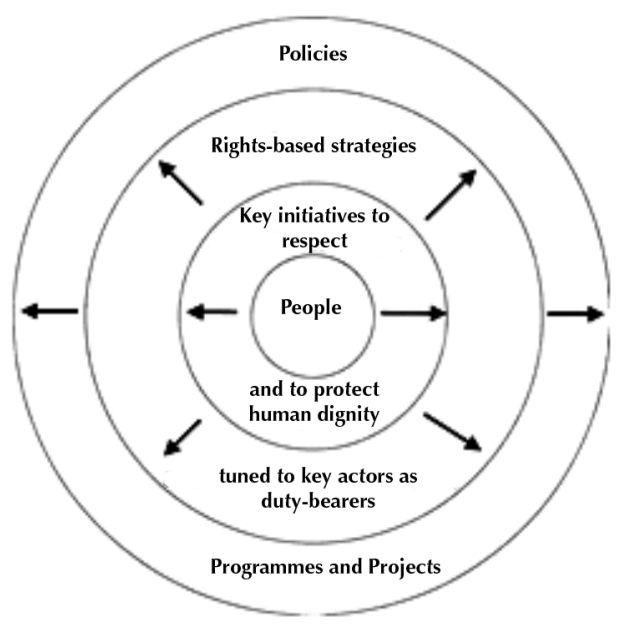

Figure 1. Upstream Human Rights (Source: Fortman, Quod Omnes Tangit.) ${ }^{28}$

Here, action begins with people in processes of self-identification as right-holders. The major challenges they face in their daily lives are to find protection against all abuses of power and to acquire the fundamental freedoms and basic entitlements that follow from respect for everyone's basic human dignity. Those at the grassroots are themselves the ones who know best what they are due within their own sociopolitical-economic context. The result, then, should be collective efforts to identify duty-bearers responsible for the often structural constraints that the right-holders face in their struggles.

Naturally, downstream and upstream strategies can be distinguished only theoretically; in reality they constitute two sides of what is basically one process: realization of the fundamental freedoms and basic entitlements that follow directly from the need to respect and protect the dignity of each and every person.

28. Bas De Gaay Fortman, Quod Omnes Tangit, in Canonical Testament. Monsignor W. Onclin ChAIR 23 (2004). 
Practical realization of the freedoms and entitlements claims that flow from human dignity is the primary perspective from which this article examines structural deficiencies in access to safe water and sanitation. A pervasive background to such analysis is on structural non-implementation in societies and communities that, from a human rights realization perspective, may be seen as disabling (adverse) rather than enabling (conducive) environments.

\section{CONCEPTUALIZING WATER IN A HUMAN RIGHTS PERSPECTIVE}

\section{A. The Assertion of a Distinct Human Right to Water and Sanitation}

The focus on a specific right to water may be partly seen as a reaction to the privatization of water utilities which started in the late 1980s, the years of so-called structural adjustment. ${ }^{29}$ Yet, it had already been welcomed and pushed forward by international development agencies such as the United Nations Development Programme (UNDP) and the World Health Organization (WHO).$^{30}$ At the 1992 International Conference on Water and the Environment (ICWE) in Dublin, the final statement declared access to clean water and sanitation (at an affordable price) a basic right of all human beings. ${ }^{31}$ The emergence of a human rights-based approach to development in the mid-1990s clearly contributed to the advancement of this endeavor, too.

From the perspective of international law, however, a "right to water and sanitation" used to be highly contested, since no reference to water is made in the Universal Declaration of Human Rights (UDHR). ${ }^{32}$ It is, however, explicitly mentioned in two UN Treaties: the Convention on the Elimination of All Forms of Discrimination Against Women (CEDAW) ${ }^{33}$ and the Conven-

29. Karen Bakker, The "Commons" Versus the "Commodity": Alter-globalization, Anti Privatization and the Human Right to Water in the Global South, 39 ANTIPODE 430, 436 (2007). Here, the author questions the suitability of a human rights-based approach to counter the market-based approach to water, arguing that the notions of human right and commodity are not fully incompatible.

30. Id. at 438 .

31. Lyla Mehta, with Oriol Mirosa Canal, Financing Water for all: Behind the Border Policy Convergence in Water Management, 4 (IDS Working Paper 233, Brighton: Institute for Dev. Stud., (2004)); The Dublin Statement on Water and Sustainable Development, International Conference on Water and the Environment (31 Jan. 1992), available at http://www.wmo.int/pages/prog/hwrp/documents/english/icwedece.html.

32. Universal Declaration of Human Rights, adopted 10 Dec. 1948, G.A. Res. 217A (III), U.N. GAOR, 3d Sess., U.N. Doc. A/RES/3/217A (1948).

33. Convention on the Elimination of All Forms of Discrimination Against Women, adopted 18 Dec. 1979, G.A. Res. 34/180, U.N. GAOR, 34th Sess., art. 14, I 2, U.N. Doc. A/34/46 (1980), 1249 U.N.T.S. 13 (entered into force 3 Sept. 1981). The Convention stipulates that states parties shall ensure to women the right to "enjoy adequate living conditions, particularly in relation to [ . . . ] water supply." 
tion on the Rights of the Child (CRC). ${ }^{34}$ Hence, the tendency was to assert adequate access to water and sanitation as being implicit in other formally recognized rights such as the right to life, to health, and to an adequate standard of living. Thus, in its General Comment No. 15 of 2002, the UN Committee on Economic Social and Cultural Rights took this position on the basis of the interpretation of Article 11 (right to an adequate standard of living) and Article 12 (right to health) of the UN Covenant on Economic Social and Cultural Rights of 1966 (UNCESCR). Subsequently, it classified water for the body as "indispensable for leading a life in human dignity" and as such "a prerequisite for the realization of other human rights." ${ }^{35}$ The Comment then specified certain crucial characteristics of international protection of access to water, viz. availability, quality, and accessibility, insisting specifically that they apply to water for personal and domestic uses.

But without any further effort to first establish conceptual clarity, the Committee then declared:

The human right to water entitles everyone to sufficient, safe, acceptable, physically accessible and affordable water for personal and domestic uses. An adequate amount of safe water is necessary to prevent death from dehydration, to reduce the risk of water-related disease and to provide for consumption, cooking, personal and domestic hygienic requirements. ${ }^{36}$

This General Comment seeks to combine deductive reasoning-rights derived from positive international law that would have to be realized-with inductive efforts to determine what people require in order to sustain their daily livelihoods. Notably, although water tends to be principally classified as a right, it is generally discussed as a set of entitlements. In that way, the deductive and inductive approaches get muddled, as becomes clear in the following statement:

The Committee notes the importance of ensuring sustainable access to water as it is required for a range of different purposes, besides personal and domestic uses, to realise many of the ESC rights. For instance, water is necessary to produce food (right to adequate food) and ensure environmental hygiene (right to health). Water is essential for securing livelihoods (right to gain a living by work) and enjoying certain cultural practices (right to take part in cultural life). Nevertheless, priority in the allocation of water must be given to the right to water for personal and domestic uses. Priority should also be given to the water

34. Convention on the Rights of the Child, adopted 20 Nov. 1989, G.A. Res. 44/25, U.N. GAOR, 44th Sess., art. 24, I 2, U.N. Doc. A/44/49 (1989), 1577 U.N.T.S. 3 (entered into force 2 Sept. 1990). The Convention requires states parties to combat disease and malnutrition "through the provision of adequate nutritious foods and clean drinkingwater."

35. General Comment No. 15, The Right to Water, adopted 20 Jan. 2003, U.N. ESCOR, Comm. on Econ., Soc. \& Cult. Rts., 29th Sess., ฯ 1, U.N. Doc. E/C.12/2002/11 (2002.

36. Id. I 2 (emphasis added). 
resources required to prevent starvation and disease, as well as water required to meet the core obligations of each of the Covenant rights. ${ }^{37}$

With the declaration of a new "right to water," the Committee exceeded its mandate rather than just interpreting the explicit language of the Covenant. ${ }^{38}$ Yet, this Committee's declaration ultimately culminated in the General Assembly declaration quoted at the onset of this article: "the right to safe and clean drinking water and sanitation as a human right that is essential for the full enjoyment of the right to life and all other human rights." ${ }^{\prime 3}$

A first conceptual question in this respect is, of course, whether such a proclamation was a legal prerequisite to the protection of water entitlements. The UDHR had already been passed in 1948, which subsequently has been endorsed through opinio iuris as well as states' practice to such an extent that its core articles in respect of the protection of basic human dignity may well be seen as customary international law. ${ }^{40}$ This includes the right to life (Article 3) as well as the right to a standard of living that is adequate in terms of health and well-being (Article 25). In the international treaty-based setting, Article 12 of the ICESCR defines the right to health as "the right of everyone to the enjoyment of the highest attainable standard of physical and mental health." Since the specification of what that entails in Article 12, paragraph 2 under 1, 2, 3, and 4 is obviously not limited, the United Nations Committee on Economic, Social and Cultural Rights (CESCR) might well have addressed water entitlements in its previous General Comment on the Right to Health (No. 14).

In downstream international human rights-representing those circles that are primarily concerned with the protection of human dignity from the perspective of international standard-setting and supervision-issues include the question of whether sets of claims that have not been explicitly recognized in legally binding documents, might nonetheless be seen as "inherent," "tangential" or "implied" rights. ${ }^{41}$ The Committee opted for the inherent position, connecting the "right to water" primarily to Article 11 (adequate living standard, with particular emphasis on housing and food) and Article 12 on health.

37. Id. ๆ 3.

38. It is only the General Assembly that can do so on the advice of the Human Rights Council.

39. General Comment No. 15, supra note 35, ब1 1.

40. Berma Klein Goldewijk \& Bas De Gaay Fortman, Where Needs Meet Rights: Economic, Social and Cultural Rights in a New Perspective 7 (1999).

41. Stephen Tully, Human Right to Access Water?: A Critique of General Comment No. 15, 23 Netherlands Q. Hum. Rts. 35, 37 (2005). 


\section{B. Limitations of Conventional Human Rights Methodology}

At the root of systemic denial of people's human dignity-related freedoms and entitlements lie gross distribution injustices in economic and political power. Thus, rather than merely a moral discourse, human rights is best conceptualized as an arena of struggle. In that light the real question to be tackled is strategy: the ends and means needed to overcome constraints to achieve complete realization of human rights. It is, indeed, not the core of the human rights mission, universal human dignity, which must be seen as problematic. As David Kennedy has noted, "[t]here is no question that the international human rights movement has done a great deal of good." ${ }^{42} \mathrm{He}$ identifies that "good" as:

freeing individuals from great harm, providing an emancipatory vocabulary and institutional machinery for people across the globe, raising the standards by which governments judge one another, and by which they are judged, both by their own people, and by [. . .] the "international community." "43

Yet, Kennedy wonders whether the "international human rights movement" must now be seen as "part of the problem:" "The strong attachment of the human rights movement to the legal formalization of rights and the establishment of legal machinery for their implementation makes the achievement of these forms an end in itself." ${ }^{44} \mathrm{He}$ specifies these "setbacks" as a mission that became legalized, bureaucratized, secluded in pretensions and promises it cannot deliver, and isolated from the world of politics and economics in which the most vital battles for justice are fought. These flaws all have to do with the ways and means in which the mission has been conceived, institutionalized and (de)contextualized..$^{45}$

Indeed, the international human rights venture was conceived without due regard for its foundational "faith" in universal human dignity, nor for the essentially political nature of a mission grounded in declared rather than conclusive rights. It was also confusingly institutionalized through a pretentious legal system subservient to international politics. ${ }^{46}$ And in its doctrinal implementation of standardized strategies all over the world it became de-contextualized, without due regard for the specificity of concrete sociocultural and politico-economic environments. From this critical perspective, possibilities of re-engineering that mission with particular regard

42. David Kennedy, The International Human Rights Movement: Part of the Problem?, 15 Harv. Hum. Rts. J. 101, 101 (2002).

43. Id.

44. Id. at 110

45. Fortman, Political Economy of Human Rights, supra note 27, at 201.

46. See Bastiaan De Gaay Fortman, Human Rights, International, in Encyclopedia of Global Studies 816 (Helmut K. Anheier \& Mark Juergensmeyer eds., 2012). 
to the prevailing deficit in access to safe water and sanitation are examined, and suggest a greater focus on legitimacy instead of legality. But first the meaning and implications of the water and sanitation deficit are explored.

\section{Limitations of a Distinct Human Right to Water and Sanitation}

The newly declared right to water would seem to have certain legal foundation. Nevertheless, this entire downstream venture of declaring new rights is faced with three critical limitations.

First, protection of human dignity by law assumes "law and order" in the sense that law functions as a way of guaranteeing security of people-in their person, in their possessions and in their legal agreements (implying that pacta sunt servanda) — and settling disputes arising from conflicting interests in an ordered manner. However, in many politico-juridical settings the role of state law is rather constrained. While there is general agreement that the state ought to have a crucial role in the protection of the basic dignity of each and every human being on its territory, it is precisely that same institution which has the highest record of gross and systematic human rights violations. ${ }^{47}$ The paradox is, of course, that for effective protection against abuse of power one needs power, and power is often abused. Moreover, effective legal incorporation of human rights into national legislation requires a well-functioning state based on the rule of law, which is all too often lacking. Notably, a June 2008 UN report estimated that four billion people live without the protection of the rule of law, ${ }^{48}$ and hence, implicitly, in an adverse environment for human rights realization. Thus, even where people's internationally proclaimed rights have been nationally declared, too, a justice gap persists, reflecting the failure of international human rights to live up to their promise.

Second, the values behind human rights norms have to be "received" in the sense of a cultural reception of the law. In reality there tend to be serious politico-cultural constraints, although these may well differ depending upon the concrete context. (Naturally, however, culture may also act as a positive factor enhancing reception of human rights based norms, standards and principles albeit not always by means of state law). ${ }^{49}$

47. Paul Gordon lauren, The Evolution of International Human Rights: Visions Seen 3 (1998).

48. Gary Haugen \& Victor Boutros, And Justice For All: Enforcing Human Rights for the World's Poor, 89 Foreign Aff. 50, 52 (2010); UNDP, Making the Law Work for Everyone Vol. 1 , at 1 (2008). This seems to be the most up-to-date information on this issue because it is also cited in the UNDP, Legal Empowerment Strategies at Work: Lessons of Inclusion from COUNTRY EXPERIENCES 18 (2014).

49. This point is emphasized in the so-called "receptor approach," which is based on the view that "the culture and existing social institutions of [. . . ] countries can actually contribute to meeting international human rights obligations." Tom Zwart, Using Local Culture to Further the Implementation of International Human Rights: The Receptor Approach, 34 Hum. Rтs. Q. 546, 547 (2012). 
Third, human rights norms do not reflect all core aspects of justice in the same way. It is particularly in respect of the principle of equality as more than just formal equality of all before the law that their meaning is limited. The explanation is that inalienable subjective rights tend to be formulated in an absolute manner- "everyone has the right to" — whereas the struggle for social justice has to be directed against substantive socioeconomic inequality, which is of a relative nature. Indeed, human rights appear to be ineffective as a normative instrument in combating growing socioeconomic inequality.

With regard to water, a review of these limitations instigates the following brief comments:

1. Luckily, law is more than just state law, official courts, and enforcement agencies. If, indeed, the realization of fundamental norms binding the use of power were purely dependent on formal legal processes, in many environments, deficits in the enforcement of crucial standards would be much worse. Fortunately, however, law can also work through informal mechanisms or as living law. Although "law" manifests itself as regulation of power, "living law" has the nature of "anti-power." Principally, it refers to informal processes of setting, monitoring, and enforcing norms pertaining to order and justice within a certain community. ${ }^{50}$ For example, through protest and resistance the building of a dam that is to cut people off from their existing water supplies may actually become impossible even if that project had already been incorporated in an act of parliament. ${ }^{51}$ Similarly, agencies supplying water to households may feel compelled to tolerate tapping off practices that are not based on any formal contract. Notably, entitlements protected by living law in citizen-state relations may well be affected by privatization policies.

2. Politico-cultural reception of access to safe water and sanitation as a human rights issue is bound to require collective action. Indeed, in many politico-economic contexts, the transformation of declared rights into conclusive rights - with guaranteed freedoms and entitlements for everyone-calls for long and enduring struggles. As for civil and political rights, it is the existing political order that needs to be confronted. In the case of

50. An illustration may be taken from the social history of slavery in Barbados. Records of slave births and sales show that from the end of the eighteenth century onwards infants were no longer sold apart from their mothers and the nuclear family became a common phenomenon among slaves, implying among other things that husbands and wives were not sold separately either Hilary Beckles, Natural Rebels: A Social History of Enslaved Black Women in Barbados 105, 107 (1989)). Apparently female slaves regarded motherhood as "a customary right"; yet there was no recognition of slaves as legal subjects since they were considered as being chattel. But slave owners feared that non-compliance would imply a considerable risk of slave revolts and hence jeopardize the whole social system. Thus what emerges is living law as noticeable self-enforcement of human rights by the right-holders through informal means.

51. Philippe Cullet, The Sardar Sarovar Dam Project: An Overview, in The Sardar Sarovar Dam Project: Selected Documents 1 (Philippe Cullet ed., 2007). 
economic, social and cultural rights it is the entitlement (sub)systems ${ }^{52}$ that lie behind structural non-implementation that would have to be changed, which means a confrontation with the economic powers.

3. Human rights litigation is ill-suited to satisfactorily address issues of human development for two major reasons, as explained by Wouter Vandenhole:

First, it takes an individualised approach to fundamentally structural problems. Secondly and at a more fundamental level, both national and international efforts to mobilise human rights law for human development seem to be frustrated and inhibited by the obstacle of presumed equality. ${ }^{53}$

However, while in international human rights law the principle of substantial rather than just formal equality is poorly embedded, ${ }^{54}$ worldviews on justice tend to take a much deeper and more encompassing perspective. Aside from political visions of social justice, reference may be made, for example, to Christian social thinking as developed in both the Roman Catholic Church and the Ecumenical Movement. ${ }^{55}$ Indeed, receptivity to the principle of fair distribution-posited by the UN General Assembly resolution on the Right to Development-requires embedding human rights struggles in religious or other inspirational sources of activism rather than just in secular human rights discourse. ${ }^{56}$

All three observations confirm a need for more than just downstream efforts that spell out all possible implications of human rights in terms of access to water. Indeed, an upstream human rights perspective appears to also be essential. This requires, first of all, an understanding of the meaning of rights in processes of acquiring basic necessities such as safe water and sanitation. Perusing general comments of the committees supervising the implementation of the various covenants and conventions, as well as the vastly increasing bulk of literature in which they are discussed, one is indeed struck by a methodological confusion in human rights terminology. Evidently, terms such as "rights," "entitlements," "access," and "freedoms" are used both as synonyms and as elements of a cocktail in which they can be freely mixed.

52. As to the meaning and significance of entitlement in respect of rights, see FORTMAN, Political Economy of Human Rights, supra note 27, at 9.

53. Wouter Vandenhole, The Limits of Human Rights Law in Human Development, in FACINC THE Limits of Law 355, 356 (Erik Claes, Wouter Devroe \& Bert Keirsbilck eds., 2009).

54. See also Bas De Gaay Fortman, Persistent Poverty and Inequality in an Era of Globalisation: Implications of a Rights Approach, in Globalization and Its New Divides: Malcontents, ReCiPES, And Reform 149, 161 (Paul van Seters, Bas de Gaay Fortman, \& Arie de Ruijter eds., 2003).

55. See Bas De Gaay Fortman \& Berma Klein Goldewijk, God and the Goods: Global Economy in a Civilizational Perspective (1998).

56. Declaration on the Right to Development, adopted 4 Dec. 1986, U.N. GAOR, 97th plenary meeting, U.N. Doc. No. A/RES/41/128 (1986). 


\section{Entitlement Failure and Human Rights}

With respect to the declaration of the ESCR Committee already quoted above- "The human right to water entitles everyone to sufficient, safe, acceptable, physically accessible and affordable water for personal and domestic uses" - one question has to be asked first: do rights really entitle people? If that were generally true, why then do so many people in our world today lack "sufficient, safe, acceptable, physically accessible and affordable water for personal and domestic uses?" In that regard, it would be preferable to speak of entitlement failure: almost one billion persons on this earth suffer from lack of access to potable water, not because resources are lacking but due to deficient entitlement. ${ }^{57}$ Notably, this deficiency relates to declared rights in general and to economic, social, and cultural rights in particular.

Should one conclude, then, that ESC rights are rights without remedies? Indeed, in much of the literature comparable arguments tend to be expressed. Rather typical for human rights discourse in the United States, for example, is Joseph Wronka's distinction between "rights as ideals," "rights as enacted," and "rights as realized." ${ }^{58}$ In that sense General Comment No. 15 of the ESCR Committee would simply constitute the beginning of a process, moving from the proclamation of a right to water as an ideal through enactment in national legislation towards realization of the entitlements necessary to daily acquire safe water.

A strong national legal basis for claims related to water and sanitation entitlements for everyone remains quite rare. However, fighting a case may not just affect the entitlement positions of the parties involved but also increase judicial awareness of all those in similar circumstances. Legal literacy programs are a way to raise awareness of people's human rights in general. A political case-by-case approach exploits protest and other forms of dissent as ways of protecting fundamental interests against policies and action that violate people's human dignity. Even in the lives of those already facing daily hardships, such resistance appears to be often necessary. But the most pressing challenges lie in persistent structural non-implementation of human

57. "Entitlement failure" is the term coined by Amartya Sen, Poverty and Famines: An Essay on Entitlement and Deprivation (1981). What is problematic, however, is that Sen identifies entitlements with rights, meaning "legal rights" as opposed to the "moral rights" that we know as human rights. In the UNDP, Human Development Report 2000 (2000)—which is substantially based on Sen's conceptual work-the terminology has moved towards "abstract" rights and "concrete rights." In our view a significantly more comprehensible way to address the issues involved in structural non-implementation of human rights is through a clear distinction between (abstract) rights and (concrete) entitlements. See Bas De Gaay Fortman, Rights-Based Approaches: Any New Thing under the Sun?, INT'L Dev. Ethics Ass'n Newsletter (2000).

58. Joseph Wronka, Human Rights and Social Policy in the 21 st Century: A History of the Idea of Human Rights and Comparison of the United Nations Universal Declaration of Human Rights with United States Federal and State Constitutions 28-30 (1992). 
rights. It is the economic, political and social structures behind situations where rights are not realized that need to be addressed. Here, collective action will be called for, aiming at structural reforms.

Fortunately, human rights imply more than just a commitment to legally protect claims based on already acquired freedoms and entitlements. The recognition of certain interests that rights entail may also provide legitimacy to a struggle for transformation, and it is precisely in respect of their transformational role that human rights may operate as a powerful instrument before any local legislation has been effectively enacted. That weaponry may take the form of legal resources as well as political means of fighting a battle.

\section{HUMAN RIGHTS-BASED STRATEGIES TO SECURE ACCESS TO SAFE WATER AND SANITATION}

Taking four cases that serve as examples to understand how legitimacy-based actions affect legality principles may illustrate how local endeavors to secure access to water and sanitation all point to a strong emphasis on legitimacy instead of "soft" legality. In the struggle to sustain daily livelihoods four different types of human rights strategies may be distinguished: (1) judicial approaches focused on individual cases one-by-one, (2) judicial approaches aimed at raising collective consciousness of issues, (3) political approaches focused on specific cases one-by-one, and (4) collective action aimed at structural reform. These may be illustrated by a simple matrix showing the focus of human rights with regard to its two major functions-protection and empowerment-as well as two categories of means towards implementation-legal resources and political instruments. It is only the protective use of legal resources - the case-by-case approach — that is based on legality, while the other three types of human rights strategy focus on legitimacy. These four cases may serve to exemplify each of these four strategic approaches by a concrete instance as shown in Table 1 below: 
Table 1. Human rights as both legal resources and political instruments in their protective as well as emancipatory functions.

\begin{tabular}{|c|c|c|}
\hline $\begin{array}{l}\text { Functional } \\
\text { Instrumental }\end{array}$ & Protective & Empowering \\
\hline Legal resources & $\begin{array}{l}\text { Litigation, mediation and } \\
\text { other forms of judicial } \\
\text { action (case by case } \\
\text { approach) } \\
\text { e.g. Santa Casa de Misericordia } \\
\text { de Santa Rosa do Viterbo (Brazil) }\end{array}$ & $\begin{array}{l}\text { Structural legal aid, legal } \\
\text { literacy programs aiming at } \\
\text { legal empowerment and } \\
\text { access to justice } \\
\text { e.g. Vellore Citizen's Welfare } \\
\text { (India) }\end{array}$ \\
\hline Political Instruments & $\begin{array}{l}\text { Protest, resistance and } \\
\text { opposition to policies and } \\
\text { actions violating human dignity } \\
\text { e.g. Water privatization in } \\
\text { Tucumán (Argentina) }\end{array}$ & $\begin{array}{l}\text { Collective action addressing } \\
\text { power relations embodying } \\
\text { injustice, while aiming at } \\
\text { structural reform } \\
\text { e.g. Social movement against } \\
\text { water privatization (South } \\
\text { Africa) }\end{array}$ \\
\hline
\end{tabular}

Thus, four specific cases may illustrate this strategic diversity in efforts to realize entitlements in respect of safe water and sanitation.

\section{A. Case 1: Legal Resources and Protective Results}

First, then, judicial activism usually works as a case-by-case approach. The national legal basis for such an approach tends to be weak. Typical disputes concern disconnection of already accessible water supplies. A case in point is Santa Casa de Misericordia de Santa Rosa do Viterbo Hospital v. Basic Sanitation Company of São Paulo State (Brazil). ${ }^{59}$

The case refers to the disconnection of water in the hospital Santa Rosa do Viterbo following non-payment. The hospital filed a judicial claim before the Court of Justice of the State of São Paulo. However, it was rejected. The case was later appealed to the Supreme Court. The Supreme Court found that although it was "legitimate" to interrupt water services due to non-payment, this did not apply to all circumstances, such as when public schools, nurseries, universities or hospitals were involved, and to do so would threaten human life. In its decision, the Court ordered the company to re-establish the water connection of the hospital.

59. S.T.J.-Recurso Especial No. 943.850-SP. (2007/0088451-6), Relator: Ministro José Delgado, 28 Aug. 2015, Santa Casa de Misericordia de Santa Rosa do Viterbo Hospital v. Basic Sanitation Company of São Paulo State (Braz.), available at http://stj.jusbrasil. com.br/jurisprudencia/13804/recurso-especial-resp-943850/inteiro-teor-100023133. 
The legal basis for this judgment rested on an Act to protect and defend consumers, which compels public utilities and their concessionaries to deliver adequate, efficient, secure and-in case of indispensability-continuous services. Although this seems to be a rather restricted grounding in positive law, there is strong support that it was based upon legitimacy. The Court made reference to an earlier judgment on disconnection of electricity that designates as illegitimate any action, which constitutes "an imminent danger to survival, health or people's security." Notably, the Judge's decision in this case just concerned the protective interests of the applicants based on special circumstances. Yet, judicial action may well have an empowering impact, too, as illustrated in Vellore Citizens Welfare Forum v. Union of India. ${ }^{60}$

\section{B. Case 2: Legal Resources and Empowering Outcomes}

Applicants stated that certain tanneries were discharging untreated effluent into agricultural fields, road-sides, waterways and open lands. The untreated effluent was ultimately discharged in the Palar River, which is the main source of water supply to the residents of the area. The Supreme Court of India found "that the tanners have absolutely no regard for the healthy environment in and around their tanneries." ${ }^{11}$ But, despite repeated extensions granted by the Court during a period of five years, and prior to that by the Board, the tanneries in the state of Tamil Nadu, "miserably failed to control the pollution generated by them." ${ }^{62}$ The Court then noted that:

[t]hough the leather industry is of vital importance to the country as it generates foreign exchange and provides employment avenues it has no right to destroy the ecology, degrade the environment and pose as a health hazard. It cannot be permitted to expand or even to continue with the present production unless it tackles by itself the problem of pollution created by the said industry. ${ }^{63}$

The Court ruled that the more than nine hundred tanneries operating in the five districts of Tamil Nadu "must compensate the affected persons and also pay the cost of restoring the damaged ecology." 64 The Court grounded its decision in legal principles such as "Sustainable Development," 65 interpreted as an evolving principle in Customary International Law. In addition, it was also grounded upon the "Precautionary principle" and the "Polluter

60. Vellore Citizens Welfare Forum v. Union of India (1996) (India), available at http:// indiankanoon.org/doc/1934103/.

61. Id. I 3.

62. Id. I 11.

63. Id.

64. Id. ๆ 20.

65. Id. 
Pays" principle. ${ }^{66}$ The Court interpreted these to mean that absolute liability for harm to the environment extends not only to compensate the victims of pollution but also to the cost of restoring the environmental degradation and "the inalienable common law right of clean environment," positive law - the Water Prevention and Control of Pollution Act of 1974 and the Constitutional and statutory provisions that shield a person's right to fresh air, clean water and a pollution free environment.

Remarkably, the Court also ordered the Central Government to create an authority with all the powers necessary to deal with the situation and other polluting industries in the State of Tamil Nadu, and it requested the Chief Justice of the Madras High Court to form a special "Green Bench" to deal with this case and other environmental matters that would pass any appropriate order/orders keeping in view the directions issued in this judgment. ${ }^{68}$

In India, with its well established practice of "public interest litigation," a case like this one is far from rare. ${ }^{69}$ Such successful empowering efforts require not only a strong legal culture and a notably activist judiciary-with the Supreme Court in the lead-but also a tough civil society engaged in legal literacy programs with a focus on practical human rights education. The reference to emerging principles of (international) law points to an obvious desire to ground judicial decisions in strong notions of legitimacy.

Where such factors conducive to an enabling sociojuridical environment do not apply, a struggle for economic justice might still build upon human rights as a protective instrument, albeit from a primarily political angle. A case in point is the protest against water privatization that was organized in an outlying area of Argentina. ${ }^{70}$

\section{Case 3: Political Instruments and Protective Results}

In 1995, a subsidiary of the transnational water company Vivendi, Aguas del Aconquija, obtained a long-term concession contract to provide water services to the province of Tucumán, in north Argentina. ${ }^{71}$ The subsequent rise of water tariffs and the deterioration of water quality (due to manganese contamination) led to the formation of two consumer associations, the Asociación de Defensa de los Usuarios y Consumidores de Tucumán

\footnotetext{
66. Id. ๆ 12.

67. Id. 13.

68. Id. ๆ 22.

69. See Fortman, Adventurous Judgments, supra note 14, at 33-40.

70. See INSEAD, Aguas del Aconquija: Privatization in Troubled Waters (04/2005-5275) (2005), available at https://hec.unil.ch/docs/files/21/280/aguasdelaconquija.pdf.

71. See Bronwen Morgan, Water on Tap: Rights and Regulations in the Transnational Governance of Urban Water Services 121 (2011).
} 
(ADEUCOT) and the Defensa de los Usuarios de Agua y Servicios (DUDAS). ${ }^{72}$ These NGOs orchestrated a series of actions (street marches, demonstrations, policy lobbying) culminating in a mass payment boycott in $1996 .{ }^{73}$ Following the intervention of the Ombudsman, who advised boycotting consumers on how to file a formal complaint with the water company, the concession contract was terminated prematurely in $1997 .{ }^{74}$ The requests of the activists were both procedural and substantive. They demanded more public participation in reform of the water sector and "social" rather than commercial tariffs as well as the prohibition of disconnections. Although the first demand remained unheard, the second was partially welcomed as the law now prohibits water cut-off to those who consume less than the basic amount. ${ }^{75}$

Since access to water and sanitation tends to be "softly" based in positive law, especially in developing countries, collective action aimed at socioeconomic justice is important to ensure that this essential entitlement connected directly to human dignity is protected. Obviously, such struggles for structural reform are much easier to conduct in environments where water has been recognized as a public utility falling under direct governmental responsibility than in the case of private suppliers. Hence, as noted above, there is a strong demand for a distinct human right to water and sanitation as a reaction to the privatization of water utilities. ${ }^{76}$

\section{Case 4: Political Instruments and Empowering Outcomes}

An illustrative case of collective action is the protests against water reforms in post-apartheid South Africa. The very first campaign aimed to advocate realization of the constitutional provisions on water-stipulating the right of everyone "to have access to . . . sufficient food and water"77_took place between 1996 and 2000, when privatization of water services was becoming popular. ${ }^{78}$ This led to the creation of several social movements, like the Anti-Privatization Forum (APF), the Anti-Eviction Campaign and the Coalition Against Water Privatization, whose actions focused on social protests and popular resistance. ${ }^{79}$ For instance, the APF operates in three distinct ways:

72. Id. at 127 .

73. Id.

74. Id. at 135 .

75. Id. at 141

76. See Water Delivery: Public or Private (Jaap de Visser \& Christopher Mbazira eds., 2006).

77. S. Africa Const., 1996, art. 27(b).

78. Jackie Dugard, Rights, Regulation and Resistance: The Phiri Water Campaign Current Developments, 24 S. Afr. J. Hum. Rts. 593, 601 (2008).

79. Id. For an interesting analysis of social movements in contemporary South Africa, see Richard Ballard, Social Movements in Post-Apartheid South Africa: An Introduction, in 
mass activities (marches, pickets, demonstrations), raising public awareness (media statements, cultural expressions), and building organization (meetings, education and solidarity activities). ${ }^{80}$ The APF insists on basic needs (housing, water, electricity, education) and engages in a struggle against "neoliberal reforms." ${ }^{81}$ Rights language has progressively made its own way into these movements as judicial action has emerged as another effective instrument to frame the same demands. Furthermore, while the degree of action of some of these movements has decreased in the last few years, a new form of civic engagement has appeared, that is the so-called "service delivery protests" which have inflamed the country since 2004. Although the reasons behind these actions are complex and need deeper analysis, ${ }^{82}$ these may well be described as local protests emanating from poor townships and informal (shack) settlements in response to the lack of basic services (especially water and sanitation) and the worsening poverty and unemployment rates throughout the country. The protests have included different kinds of action ranging from mass meetings to drafting of memoranda, from processions to election boycotts, from blockading of roads to burning of tires and destruction of buildings, sometimes even with violent responses from the police forces. ${ }^{83}$

In sum, these four distinct cases illustrating local endeavors to secure access to water and sanitation all point to a strong emphasis on legitimacy rather than "soft" legality as a normative foundation for contentious action. It is from this perspective that current strategic approaches in the international UN-based setting are examined.

\section{INSTITUTIONALIZING WATER IN A UN-BASED SETTING}

\section{A. The Development Perspective}

International strategies for development are habitually based on economic growth with distribution as a secondary requisite. After a period in which the

Democratising Development: The Politics of Socio-Economic Rights in South Africa 77-96 (Peris Jones \& Kristian Stokke eds., 2005); Luke Sinwell, Is "Another World" Really Possible? Re-examining Counter-Hegemonic Forces in Post-Apartheid South Africa, 38 Rev. Afr. Pol. ECON. 61 (2011).

80. Sakhela Buhlungu, Centre for Civil Society \& School of Development Studies, University of KwaZulu-Natal, The Anti-Privatization Forum: A Profile of A Post Apartheid Social Movement 7 (2004).

81. Although this struggle does not seem so grounded in the common practice of its affiliates, as noted by Sinwell, supra note 79 .

82. An excellent starting point, however, is Peter Alexander, Rebellion of the Poor: South Africa's Service Delivery Protests-A Preliminary Analysis, 37 Rev. Afr. Pol. Econ. 25 (2010).

83. Id. at 26-27. 
emphasis was on international redistribution - the 1970s focus on a "New International Economic Order" — the orientation in the 1980s shifted towards national restructuring of governance and finance. Conditional financial facilities provided by the World Bank and the International Monetary Fund as the main leverage on national governments were used to cut down on the overspending state. Yet, "structural adjustment" resulted in rising poverty, too. At the end of the first millennium a new instrument was launched to promote "pro-poor" elements in national development planning: the Highly Indebted Poor Countries Initiative (HPIC), which required poor countries to draft and accept a "Poverty Reduction Strategy Paper." Analysis of these documents and their follow-up reveals some re-allocation of public finance to health and education but no significant focus on the lives of the poor themselves, including their lack of safe water and sanitation. ${ }^{84}$

The millennium year 2000 saw a major effort at institutionalization of the global struggle for safe water and sanitation in the international development community through the declaration of a set of "Millennium Development Goals" (MDGs) as internationally endorsed objectives to be reached by 2015. The targets aimed to halve the proportion of the global population suffering from lack of means towards decent daily livelihoods and lack of access to essential public services, including MDG Target 7C, which aimed to halve the proportion of people without sustainable access to safe drinking water and basic sanitation.

Such goals - succeeded now by a new "Post-2015 Development Agenda" with seventeen "Sustainable Development Goals" and 169 "associated targets" ${ }^{\prime 5}$ _address long-term macroeconomic poverty rather than the lives of the poor. It is true that they transcend approaches based only on pure income poverty by including health, education, basic amenities, reproductive health and environmental sustainability. Yet, intermediate and final assessments reveal that this approach lacks clear mechanisms and instruments for implementation. They are, indeed, just "development goals" assumed to influence policies, particularly in the field of development cooperation. The effects of efforts to monitor progress towards such goals remain unclear. Obviously, additional standards would have to be set that concern people's daily livelihoods here and now, while benchmarking is likely to

84. See Bas de Gaay Fortman, Prof. of Political Econ., Inst. of Soc. Studies, Valedictory Address, Power and Protection, Productivism and the Poor, Noordeinde Palace, The Hague (20 Nov. 2002).

85. SeeTransforming Our World: the 2030 Agenda for Global Action, Final Draft of the Outcome Document for the UN Summit to Adopt the Post-2015 Development Agenda (2015), available at https://sustainabledevelopment.un.org/content/documents/7603Final\%20draft $\% 20$ outcome\%20document\%20UN\%20Sept\%20Summit\%20w\%20letter_08072015.pdf (to be adopted in September 2015). 
have an impact only where coupled with mechanisms for monitoring ${ }^{86}$ and implementation. Notably, five years before the target year 2015 a shift in the international focus from the MDGs towards "rights-based" approaches was already noticeable. Indeed, during a UN summit in New York to review progress on the MDGs, Amnesty International declared: "The Millennium Development Goals are failing the world's poorest people because governments are ignoring and abusing their human rights." 87

\section{B. The Human Rights Perspective}

In the institutional setting of international human rights, water and sanitation rights are primarily connected to ESC rights. With the substitution of the "Human Rights Council" for the previous "Commission on Human Rights" — both operating under the United Nations Charter - there is now a requirement to periodically review all states, instead of a selected few. In these Universal Periodic Reviews (UPRs), issues concerning water are also considered. The information that is submitted includes reports of special rapporteurs and treaty-based committees. NGOs also bring information to the table.

Notably, the examination of all 193 UN member states through a kind of peer review with a "troika" of three countries preparing a first list of questions tends to be seen as the major institutional step forward as compared to the Commission. Yet, this type of assessment is hampered by conventional UN procedures, based as these are on consensual approaches, in connection with the doctrine of equality of state (for instance, there are three hours devoted to plenary discussion whether it is China or San Marino which faces review). Moreover, the Human Rights Council remains a gathering of peers and, indeed, a number of these have appalling human rights records.

The substance of the recommendations that the countries have received from their "peers" is revealing. Notably, it is one particular country-usually

86. As noted in United Nations, The Millennium Development Goals Report 2011, at 66 (2011), available at http://www.un.org/millenniumgoals/pdf/\%282011_E\%29\%20MDG\%20 Report\%202011_Book\%20LR.pdf.

Improved data and monitoring tools are crucial for devising appropriate policies and interventions needed to achieve the MDGs. Although some progress is being made, reliable statistics for monitoring development remain inadequate in many poor countries, and the challenge of building in-country capacity to produce better policy-relevant data is enormous. Building such capacity demands increased and well-coordinated financial and technical support from development partners. It also requires country ownership and government commitment to spur the institutional changes needed to ensure the sustainability of capacity-building efforts.

87. Amnesty International, Failure to Respect Human Rights Means MDGs are Excluding the Poorest People (16 Sept. 2010, 2:00 AM), http://www.amnesty.org.au/news/comments/23698/. 
then joined by others - that comes up with a specific recommendation to the country under review. Safe water and sanitation discussions tend to be highly general. Perusing the UPR database phrases like the following might be found, "Continue advancing its efforts to improve indicators regarding [ . . . ] access to water with the cooperation of the international community, in particular the developed countries, which must increase their official development aid and other forms of aid" (Cuba to Bhutan supported by the Organization of American States (OAS) and several other institutional bodies). ${ }^{88}$ Such recommendations are rarely rejected but either accepted or not responded to. ${ }^{89}$ The Advocates for Human Rights (TAHR) have published an Excel document in which there is a column for "follow-up," but so far that does not contain any concrete information on what happened after recommendations had been given.

The reports submitted by national NGOs tend to be much more substantial. ${ }^{90}$ Generally, there is critical discussion of policies such as privatization, development-induced displacement and efforts aimed at full cost recovery, also from those living in daily hardship. The normative basis for such judgmental communications on the part of civil society tends to be found in strong notions of legitimacy rather than in (international) soft law.

Perhaps the most effective role of the Council lies in the appointment of special rapporteurs and working groups with a special mandate. Thus, concrete research is done concerning actual violations and their causes. It is especially through the cooperation of international and local NGOs that this contributes to public exposure of human rights abuse. Thus, it was the HRC that appointed an "Independent Expert on the issue of human rights obligations related to access to safe drinking water and sanitation" in 2008. After the General Assembly resolution on a "right to water" this position was renamed as "Special Rapporteur on the human right to safe drinking water and sanitation" (Catarina de Albuquerque). She "carries out thematic research, undertakes country missions, collects good practices, and works with development practitioners on the implementation of the rights to water and sanitation." ${ }^{91}$ The following issues served as a starting point for her mandate:

88. See Database on the Universal Periodic Review Recommendations and Voluntary Pledges, UPR-INFO.ORG, http://www.upr-info.org/database/ (last visited July 30, 2015) (the "issue" drop-down menu allows filtering by "right to water").

89. An exception is Namibia's rejection of a recommendation by Chile, the OAS, and others to invite the Independent Expert on the issue of human rights obligations related to access to safe drinking water and sanitation for a country visit.

90. These may be traced at UPR-INFO.ORG, http://www.upr-info.org/en/all-documents-by/ Summary-of-other-stakeholders-information (last visited July 30, 2015) (allowing "Summar[ies] of other stakeholders information" to be viewed by session).

91. See U.N. Office of the High Commissioner for Human Rights, Overview of the Mandate, OHCHR.ORG, http://www.ohchr.org/EN/Issues/WaterAndSanitation/SRWater/Pages/Overview. aspx (last visited July 30, 2015). See also Madeline Baer \& Andrea Gerlock, A Study of Global and Local Discourses, 36 THIRD WORLD Q 1527 (2015). 
1. the normative content of human rights obligations in relation to access to sanitation;

2. the human rights obligations attached to the elaboration of a national strategy on water and sanitation (published on 4 July 2011); ${ }^{92}$

3. the regulation of the private sector in the context of private provision of safe drinking water and sanitation;

4. criteria to protect the right to safe drinking water and sanitation in case of disconnection; and

5. the specific obligations of local authorities. ${ }^{93}$

With regard to the MDGs, Human Rights Council Resolution 7/22 requested the Special Rapporteur (SR) —-then the "Independent Expert" - to make recommendations that could help their realization, in particular Goal $7 .{ }^{94}$ To carry out this task, she consulted with actors working on the MDGs related to water and sanitation and carried out research on that topic. She presented a report to the General Assembly in October 2010 analyzing the MDG targets on water and sanitation from a human rights perspective, and concluded with recommendations on how these targets could be better aligned with human rights criteria. ${ }^{95}$

The SR noted that the MDGs do not employ the language of human rights and that between these two instruments there are significant gaps. ${ }^{96}$ Yet, P.B. Anand, for one, argued that there is a link between MDGs and human rights, as the former may be interpreted as emanating from the right to life and the right to development. ${ }^{97}$ In line with such views, the Human Development Report (HDR) 2006, which addressed the issue of water scarcity from the perspective of asymmetries of power, assumed that access to water constituted a fundamental human right. ${ }^{98}$ All this points to a strong supplementary need for contextual approaches. The same applies to de Albuquerque's 2011 report to the HRC, which ends with "Conclusions and

92. Report of the Special Rapporteur on the Human Right to Safe Drinking Water and Sanitation, Catarina de Albuquerque, U.N. GAOR, Hum. Rts. Council, 18th Sess., agenda item 3, A/HRC/18/33 (2011) [hereinafter Report of the Special Rapporteur on Safe Drinking Water].

93. Id.

94. This request literally follows Catarina de Albuquerque's own recommendation in her first report to the HRC.

95. Human Rights Obligations Related to Access to Safe Drinking Water and Sanitation, 65th Sess., Item 69 (b) of the provisional agenda, U.N. Doc. A/65/254 (2010).

96. Id. at 3,4 .

97. P.B. Anand, Right to Water and Access to Water: An Assessment, 19 J. INT'L Dev. 511, 512 (2007).

98. UNDP, Human Development Report 2006: Beyond Scarcity-Power, Poverty and the Global WATER CRISIS (2006) available at http://hdr.undp.org/sites/default/files/reports/267/hdr06complete.pdf. 
recommendations: how the human rights framework helps to improve planning," divided into four sections_-"Providing a framework for prioritization," "Providing a framework for ambitious, but realistic planning," "Ensuring sustainability," and "Emphasizing accountability" - apparently all tuned to ensuring water entitlements through policies and programs from above..$^{99}$

In the United Nations Treaty-based setting, it is particularly the Committee on Economic, Social and Cultural Rights (CESCR) that is called upon to contribute towards the attainment of entitlements like those regarding safe water and sanitation. Apart from General Comments such as No. 15 of 2002 already examined above, it is the Country Reports in which one would expect a clear focus on the problematique behind non-implementation. Thus, in the case of Brazil one finds a concluding recommendation "that the State party adopt additional measures to deal with the problem of [. . .] disadvantaged and marginalized individuals and groups and improve the water and sanitation facilities of existing housing units." ${ }^{\prime 100}$ Generally, both country reports and concluding observations on state obligations in cases in which safe water and sanitation are obvious human rights issues, are far from specific while lacking any kind of attention to power relations behind non-implementation.

This raises the question whether "rights-based strategies" grounded in international downstream efforts would suffice in overcoming constraints in respect of access to safe water and sanitation? Obviously, this requires tuning these to particular contexts of structural non-implementation. There is good reason to complement these international downstream efforts with upstream struggle by those whose vital needs for safe water and sanitation activate their internationally declared rights, as reflected in the Figure below.

99. Report of the Special Rapporteur on Safe Drinking Water, supra note 92.

100. Consideration of Reports Submitted by States Parties Under Articles 16 and 17 of the Covenant, Concluding Observations of the Committee on Economic, Social and Cultural Rights, U.N. ESCOR, 42d Sess., U.N. Doc. E/C.12/BRA/CO/2 (2009). 


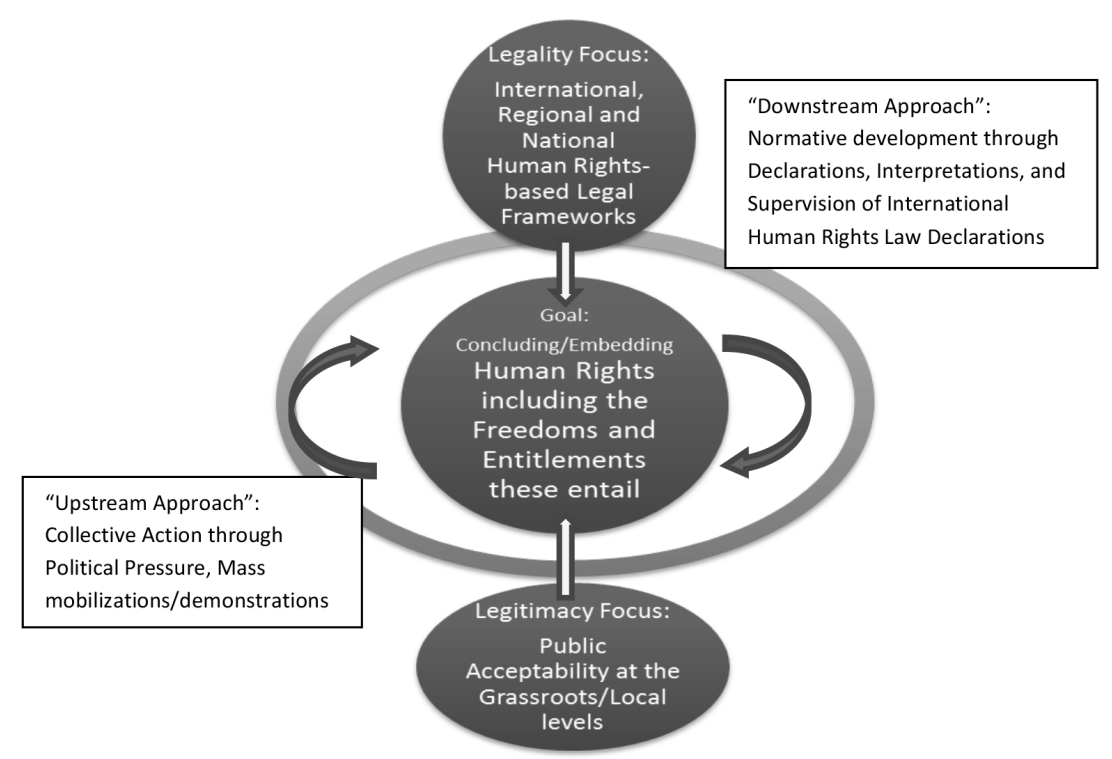

Figure 2. Necessity of Joint Downstream /Upstream Efforts in Human Rights Realization

\section{CONTEXTUALIZING WATER IN A HUMAN RIGHTS PERSPECTIVE}

Naturally, people lacking entitlement positions protecting established access to safe water and sanitation tend to find themselves engaged in daily struggles to sustain their livelihoods. Hence, in respect of context, it is important to consider the Voices of the Poor studies. ${ }^{101}$ These studies were commissioned by the World Bank as a necessary piece of research, preceding its own World Development Report 2000/2001: Attacking Poverty. ${ }^{102}$

When asked what she saw as the main finding of the Voices of the Poor studies, which had been undertaken under her guidance to prepare Attacking Poverty, Deepa Narayan's response was: "Participation!"103 The crux, in other words, lies in development processes that include rather than exclude the weaker and more vulnerable sections in society. Stimulated by the appointment of a Special Rapporteur on the "Right to Development"

101. Deepa Narayan, Voices of the Poor: A 23 Country Study for the WDR 2000/1 on Poverty, Stiglitz Summer Research Workshop on Poverty, Wash. D.C. 6-8 July 1999).

102. World Bank, World Development Report 2000/2001: Attacking Poverty (2000).

103. Interview with Deepa Narayan, Internationale Samenwerking (Aug. 2002) (on file with authors). 
to the UN Commission on Human Rights ${ }^{104}$ (fourteen years after the UN General Assembly Declaration on "The Right to Development"), the World Bank decided to take this right as a new guideline to its policies. ${ }^{105}$ The new element which the Declaration, already recognizing notions in respect of human dignity, had added was "free and meaningful participation in development and in the fair distribution of the benefits resulting therefrom."106 In the Bank's development efforts this clause would seem to imply, among other things, a persistent focus on participation and distributional equity from grassroots level. ${ }^{107}$ The point is made, rather strongly, in the tenth guideline of "A Human Rights Approach to Poverty Reduction Strategies," drafted under the auspices of the United Nations High Commissioner for Human Rights. ${ }^{108}$ Consequently, as is pointed out:

A human rights approach to poverty reduction also requires active and informed participation by the poor in the formulation, implementation and monitoring of poverty reduction strategies. The international human rights normative framework includes the right to take part in the conduct of public affairs. This is a crucial and complex human right that is inextricably linked to fundamental democratic principles. A democratic social order based on constitutionalism and free and fair elections is an essential prerequisite for enjoyment of this right. However, effective participation by the poor requires more than a functioning democracy. It calls for specific mechanisms and detailed arrangements at different levels of decision-making that help to overcome the impediments that the poor, and marginalized groups in general, face in playing an effective part in the life of the community. ${ }^{109}$

By putting participation first, the rights-based approach implies that increasing productivity - the usual primary focus of development-no longer operates as the central moving force of a system driven by return on capital investment, but instead to income-generating opportunities for the poor themselves. Where people are considered to be central as human beings with rights, macroeconomic policies ensuring a growth-conducive environment, are reduced to the secondary status. Thus, the central question becomes: growth by and for whom? Indeed, the right to development signifies not only protection against anti-poor policies and measures, ${ }^{110}$ but

104. Since 2007 transformed into the Human Rights Council.

105. As noted by Alfredo Sfeir Younis, the Bank's Special Representative to the United Nations and the World Trade Organization, Geneva (Sept. 2000) (unpublished conference paper on file with the authors).

106. Declaration on the Right to Development, supra note 56, art. 2, ฯ 3,

107. See also Irene I. Hadiprayitno, Food Security and Human Rights in Indonesia, 20 Dev. Prac. 122 (2010).

108. Un Office of the High Commissioner for Human Rights, Draft Guidelines: A Human Rights Approach to Poverty Reduction Strategies (2002), available at http://www.unhcr.org/refworld/ docid/3f8298544.html.

109. Id. ब 10 .

110. Id. 
also legitimates the struggle for "pro-poor growth" in the sense of upstream growth, as against merely growth pro-poor, seen as merely growth with some redistribution. It is, as was already argued, crucial to understand and expose the roots of economic injustices. A relevant tool here is entitlement systems analysis as illustrated in the following figure:

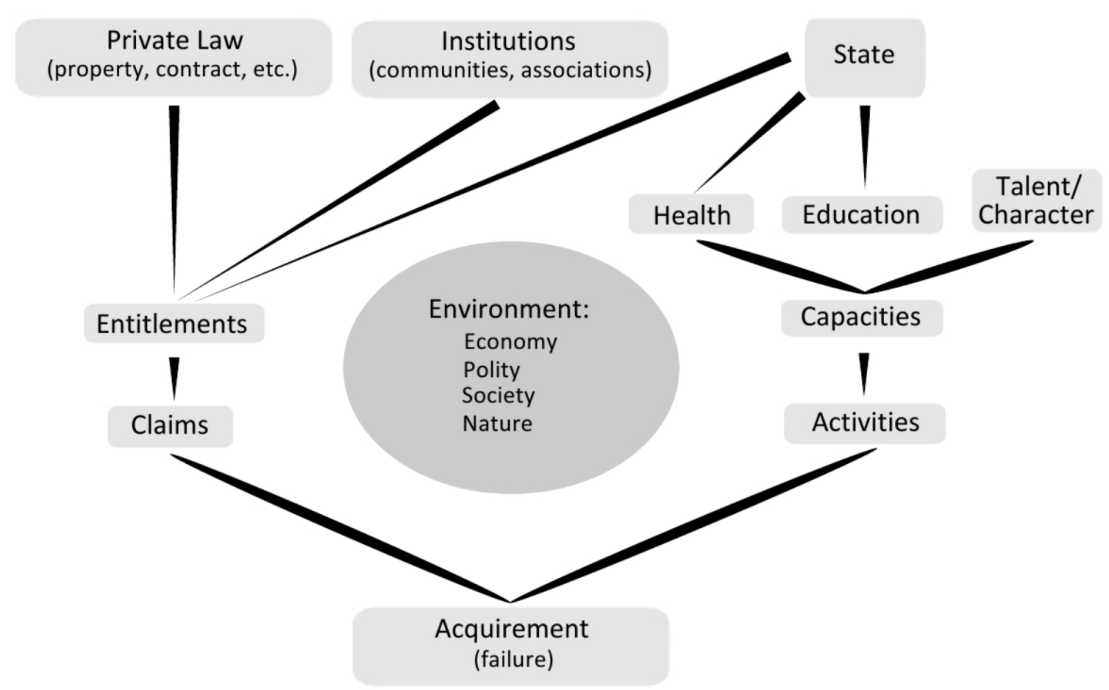

Figure 3. Acquirement Failure in Respect of Distinct Structural Sources of Entitlement (Based upon Fortman, Political Economy of Human Rights 25, note 27)

The center of this figure depicts the environment in which people attempt to acquire sustainable livelihoods. ${ }^{111}$ In situations of structural acquirement failure, these are likely to be highly adverse in terms of a malfunctioning economy, bad government, and serious sociocultural constraints, as will be further discussed below in respect of water and sanitation. Actual acquirement is a matter both of activities and honored claims; in order to work the land, for example, one needs access. While a person's activities are rooted in her capacities, claims find their basis in entitlements, that is, legitimate access to resources and legitimate command over goods and services. The figure represents three distinct entitlement systems: direct access to resources, affiliation to institutions, and arrangements by the state. Once more, specific cases may serve to exemplify the methodology put forward.

111. For more information on environmental factors and the poor in a "many-stranded web" See Fortman, Political Economy of Human Rights, supra note 27, at 141. 


\section{A. The Need for National Efforts in Attaining International Rights: Bon Vista Mansions}

It is particularly in respect of acquired rights based on property and contract that state law may serve to protect direct access to resources. An illustrative case regarding access to water is Bon Vista Mansions. ${ }^{112}$

A resident of the Bon Vista Mansions in Johannesburg claimed that the Southern Metropolitan Local Council, a local authority, had unlawfully discontinued their municipal water supply late on the afternoon of 21 May 2001. ${ }^{113}$ Together with others he had for three days attempted to seek redress through the manager of the premises, but without any success. ${ }^{114}$ In desperation, he had asked for interim relief from the South African High Court (Witwatersrand Division) in the form of an order on the Respondent to restore their water supply, pending the final determination of an application for similar relief. ${ }^{115}$

Motivating his decision to grant an interim order to restore the water supply to Bon Vista Mansions, Judge Budlender defined the consequences of the constitutional provisions in relation to the Water Services Act as follows: "If a local authority disconnects an existing water supply to consumers, this is prima facie a breach of its constitutional duty to respect the right of (existing) access to water, and requires constitutional justification." 116 Concluding that the Council had not produced evidence to show that its actions met the burden of proof required by the constitution and the Water Services Act, the judge concluded that "the Applicants had shown at least a prima facie right to a continuing supply of water, which had been infringed in that they had been deprived of access to water, and the deprivation was continuing." 117 They had no other satisfactory remedy. He, therefore, exercised his discretion to grant an interim order wherein the Council was ordered to restore the water supply to Bon Vista Mansions. ${ }^{118}$

Quite conducive to the judgment in this case was the way in which entitlements to safe water and sanitation had already been incorporated in South Africa's Constitution ("the right to have access to [. . .] sufficient food and water") $)^{119}$ as well as in its administrative law (the Water Services Act). ${ }^{120}$ Indeed, the Bon Vista case in which the Judge's decision served the

112. Residents of Bon Vista Mansions v. Southern Metropolitan Local Council 2001, High Court of South Africa (Witwatersrand div.), Case No. 01/12312 (2001).

113. Id.

114. Id.

115. Id.

116. Id. at 7 .

117. Id. at 9

118. Id.

119. S. Africa Const., art. 27(b)

120. Water Services Act of 1997, Vol. 390, No. 18522 (S. Afr.). 
interests of the applicants in just one particular dispute, aptly illustrates the value of a judicial case-by-case approach in the context of a reasonably functioning legal system.

However, even in such a favorable legal setting, rights will not automatically be realized. The primary responsibility for implementation of subjective rights rests, as it always must be, with the legal subjects. Indeed, it is these right-holders themselves who have to come into action, as they did in Bon Vista Mansions. Besides general access to justice, the second element in acquirement strategies is based on direct access to resources and the need for concrete legal activism.

\section{B. The Need for Institution-Based Entitlements: The Coca-Cola Case}

An illustrative case involving institution-based entitlement is Plachimada and Ballia Bottling Plants of Hindustan Coca-Cola Beverages (HCCB) Pvt. Ltd. These two Coca-Cola bottling plants, constructed in 2004, affected access to clean groundwater of tens of thousands of people -primarily farmers-living around these factories. ${ }^{121}$ Coca-Cola's extraction and pollution of water resources had such severe consequences on water quality that women were forced to walk miles further everyday to seek potable water for household use because the wells and water pumps in the area had dried up or were no longer safe for drinking. ${ }^{122}$ Farmers, moreover, lost their livelihoods because there was not enough water for successful crop production. Children were taken out of schools so that they could help the family get water or earn a livelihood. ${ }^{123}$

Community-led "People's campaigns" against the Coca-Cola bottling plants-with national and international support-forced their closure as of March $2004^{124}$ while a proposed third plant-in Sivaganga-was stopped from being built. But that was not the end of it. After more than 3,000 days of protest and on the basis of the recommendations in a report from a "High Power Committee" the Kerala state government set up a dedicated legal agency "to assess the actual compensation due to every applicant and issue orders to the company for compliance." ${ }^{125}$ Against fears that this would undermine the investment climate in the state, such a tribunal was nevertheless proposed to offer compensation to victims of industrial pollution. ${ }^{126}$

121. The Rights to Water and Sanitation, Case Against Coca-Cola Kerala State: India (n.d.), available at http://www.righttowater.info/rights-in-practice/legal-approach-case-studies/ case-against-coca-cola-kerala-state-india/.

122. Id.

123. Id.

124. R. Krishnakumar, Plachimada's Claims, 27 Frontuine 17-30 (2010).

125. Id.

126. Id. 
Strikingly, in this case the entitlements to safe water that had been affected were community-based while the procedures to assess compensation were tuned to individual claims.

\section{Need for Active Participation: Yacyretá Hydroelectric Project}

An illustrative case involving state-arranged entitlement is Yacyretá Hydroelectric Project (Argentina/Paraguay). In 1997, wells had been contaminated in communities in the areas of the urban creeks, downstream from Encarnación. The ecological damage appeared to be causally related to the construction of a dam in the river Paraná, close to the island of Yacyretá. ${ }^{127}$ The World Bank's Panel of the Independent Investigation Mechanism concluded that Bank administration personnel were deficient in not detecting violations of the Inter-American Development Bank's environmental policies. ${ }^{128}$ The Panel also determined that "there are serious health problems throughout the project area, many related to the high levels of coliform bacteria encountered in the water." ${ }^{129}$ Indeed, it struck the Panel as noteworthy "that, after an allocation of US\$130 million for resolving social and environmental problems, the measure of success of health issues should be that the project area is no worse than the rest of Paraguay." ${ }^{130}$ After all, the Panel concluded that "resettlement plans must take environmental considerations into account; and that an environmental impact assessment, including carrying capacity and socio-economically induced impacts on the host community, must be carried out for each proposed site." ${ }^{\prime 131}$ Obviously, then, public political policies and projects may affect people's entitlements in both positive and negative ways. Dispute settlement in such cases tends to be of a publicpolitical character, too.

Thus, in decision-making processes affecting water resources, active participation of those confronted with possible negative consequences should be seen as an essential condition to realize people's economic, social and cultural rights. Furthermore, effective and functioning accountability mechanisms, working at the different levels on which entitlement systems are based (private law, institutions and the state), should also be ensured.

127. Walter leal Filho, Julio Ruiz Murrieta, Arthur Heyman, Final Report of the Panel of the Independent Investigation Mechanism on Yacyretá Hydroelectric Project, 760/OC-RG (2004).

128. Id.

129. Id. at 4

130. Id.

131. Id. at 5 . 


\section{CONCLUSION}

This comparative analysis of institutional settings and cases has shown that neither the proclamation of development objectives nor the declaration of human rights alone can secure access to water and sanitation for the poor per se, since even such basic entitlements are rooted in power relations as displayed by socio-economic inequity. Entitlement systems analysis may reveal concrete causes of acquirement failure as apparent in deficient access to essential services. But such analysis and the advocacy and assistance based on it, will have to be complemented by action. Action is so important because "[a] focus on the whole social environment reveals . . . that people have not only rights but obligations as well, not only freedom but responsibility." ${ }^{132}$ Even in countries which have incorporated access to clean water as a right in their Constitution-such as South Africa-active participation and upstream action by the right-holders is crucial.

Notably, the judicial and political approaches analyzed here have shown the importance of the role played by civil society in helping the poor acknowledge that they have rights, too, and thereby, can legitimately demand the state (and other institutions) be accountable to them. Moreover, the various cases examined here have illustrated the relevance of local contexts in determining which forms of collective action might be attempted by the poor. Thus, human rights strategies are not to be employed as uniform approaches regardless of specific economic-political and socio-legal contexts. The high degree of public legitimacy, which characterizes human rights, may constitute a basis for collective action aimed at enhancing structural transformations in contexts of established inequality. Indeed, this research underscores the following observation by Jack Donnelly:

The transformative, even constitutive, effects of such norm-driven political practices deserve emphasis. The international law and politics of human rights is largely concerned with fostering acceptance of shared standards of decency and respect. This most immediately involves pressuring states to do the decent thing with respect to their own citizens. At a deeper level, however, international human rights norms aim to (re)shape national and international interests, institutions, and practices-and thus to construct states of a particular kind, as well as a particular kind of international law and international relations. ${ }^{133}$

Finally, the recent attention towards water and sanitation within the international community (particularly the UN General Assembly and the HRC) may be interpreted as an overdue acknowledgement that the deprivation suffered by people lacking essential services is severe enough to demand

132. Fortman, Political Economy of Human Rights, supra note 27, at 24.

133. Jack Donnelly, The Virtues of Legalization, in The Legalization of Human Rights 67, 75 (Saladin Meckled-García \& Başak Çali eds., 2006). 
immediate judicial and political intervention. Naturally, downstream initiatives flowing from this international recognition remain important. Yet, it is also imperative to recognize that these can be effective in realizing human rights at the local level only if also accompanied by grassroots/upstream efforts to transform the political and economic structures behind deficient access to water resources. 